\title{
Adetogramma (Polypodiaceae), a new monotypic fern genus segregated from Polypodium
}

\author{
Thaís Elias Almeida', Alexandre Salino², \\ Jean-Yves Dubuisson ${ }^{3,4}$, Sabine Hennequin ${ }^{3,4}$
}

I Universidade Federal do Oeste do Pará - Herbário HSTM, Avenida Marechal Rondon, s.n. - Santarém, Pará, Brazil. CEP: 68040-070 2 Programa de Pós-graduação em Biologia Vegetal - Departamento de Botânica, Universidade Federal de Minas Gerais, Av. Antônio Carlos, 6627 - Belo Horizonte, Minas Gerais, Brazil. Caixa Postal 486, CEP 31270-901 3 Institut Systématique Evolution Biodiversité (ISYEB), Sorbonne Universités, UPMC Univ. Paris 06, MNHN, CNRS, EPHE, 75005 Paris, France 4 Centre de Recherche en Paléobodiversité et Paléoenvironnements (CR2P), Sorbonne Universités, UPMC Univ. Paris 06, MNHN, CNRS, 75005 Paris, France

Corresponding author: Thaís Elias Almeida (blotiella@gmail.com)

Academic editor: B. Leon | Received 9 February 2017 | Accepted 1 April 2017 | Published 13 April 2017

Citation: Almeida TE, Salino A, Dubuisson J-Y, Hennequin S (2017) Adetogramma (Polypodiaceae), a new monotypic fern genus segregated from Polypodium. PhytoKeys 78: 109-131. https://doi.org/10.3897/phytokeys.78.12189

\begin{abstract}
Polypodiaceae is one of the most diverse and abundant families of ferns in tropical and subtropical forests. Despite multiple studies investigating its phylogeny and taxonomy, several generic boundaries within the family still need clarification. One of the most problematic circumscriptions is that of Polypodium L., and one species that still contributes to this uncertainty is Polypodium chrysolepis Hook. The main goal of this study was to use molecular and morphological data to clarify the relationships of $P$. chrysolepis inside the polygrammoid clade. Sequences from three plastid regions (cpDNA - rbcL, rps 4 and $r p s 4-t r n S$ IGS) from fifty species belonging to thirty-two genera of Polypodiaceae were analyzed using maximum likelihood and Bayesian inference. Polypodium chrysolepis constitutes an isolated lineage among the neotropical polygrammoid ferns, close to Serpocaulon and the grammitids, and is recognized here in a new genus. It can be distinguished by its entire leaves with free veins and peltate, pedicellate, lanceolate paraphyses. A new combination, Adetogramma chrysolepis, is proposed and a new taxonomic treatment is presented; its conservation status was assessed using IUCN Red List Categories and Criteria.
\end{abstract}

\section{Keywords}

Andes, Polypodiaceae, phylogeny, Serpocaulon, taxonomy

Copyright Thaís Elias Almeida et al. This is an open access article distributed under the terms of the Creative Commons Attribution License (CC BY 4.0), which permits unrestricted use, distribution, and reproduction in any medium, provided the original author and source are credited. 


\section{Introduction}

Polypodiaceae is one of the richest fern families, and one of the most diverse and abundant groups of vascular plants in tropical and subtropical forests (Schneider et al. 2004). The current family circumscription (PPG I 2016) is based on many phylogenetic studies (e.g., Schneider et al. 2004, Schuettpelz and Pryer 2007). With this definition, Polypodiaceae includes the large segregate family, Grammitidaceae (sensu Parris 1990), and comprises 65 genera (PPG I 2016). Despite multiple studies investigating the phylogeny and taxonomy of Polypodiaceae, Smith et al. (2008) recognized that certain generic boundaries within the family still need clarification.

One of the most problematic circumscriptions is that of Polypodium L. (Smith et al. 2008). As recognized by Hennipman et al. (1990), Polypodium is polyphyletic, and several groups historically included in it (Hennipman et al. 1990) have been recognized as other genera [e.g., Goniophlebium (Blume) C.Presl, Microgramma C.Presl (Salino et al. 2008), Pleopeltis Willd., Phlebodium (R.Br.) J.Sm. (Otto et al. 2009), Serpocaulon A.R.Sm. (Smith et al. 2006a), Synammia C.Presl (Schneider et al. 2006)]. Nevertheless, recognition of all the above-cited genera still does not render Polypodium monophyletic (Schneider et al. 2004, Otto et al. 2009, Assis et al. 2016). In its latest circumscription (PPG I 2016), the genus is considered presumably monophyletic, but the groups that remain in it [Polypodium dulce group, Polypodium plesiosorum group, and Polypodium colpodes group (Tejero-Díez 2005, Sigel et al. 2014)], still need to be comprehensively included in phylogenetic studies.

One species that still contributes to this uncertainty is Polypodium chrysolepis Hook., a species occurring in the Andes from northern Argentina to Ecuador. The generic placement of this species has been controversial: it was described in Polypodium by Hooker (1844) in Icones Plantarum, tentatively placed in Lepicystis [now treated within Pleopeltis (Smith and Tejero-Díez 2014)] by Diels (1899), recognized as a distinct entity within Polypodium by de la Sota (1960) and placed in Microgramma by Crabbe (1967), following notes by A.H.G. Alston. The first molecular phylogenetic placement of P. chrysolepis (Schneider et al. 2004) showed that none of the above-mentioned generic positions are acceptable. In Schneider et al. (2004), P. chrysolepis was recovered as sister to the Serpocaulon+grammitids clade, and it is distantly related to the campyloneuroid clade (which includes Campyloneurum, Microgramma, and Niphidium) and to Polypodium s.s. clade. No formal taxonomic changes were proposed for P. chrysolepis by Schneider et al. (2004), as its position was ambiguous, and since then no new studies have been conducted on this species.

The main goal of this study was to employ molecular and morphological data to investigate the relationships of Polypodium chrysolepis within the polygrammoid clade, and to use available morphological and phylogenetic information to formally propose an adequate generic placement for this species in Polypodiaceae. 


\section{Material and methods}

\section{Taxon sampling}

Fifty species from thirty-two genera (sensu PPG I 2016) of Polypodiaceae were included in our phylogenetic analyses (Appendix). Davallia solida (G.Forst.) Sw. (Davalliaceae) and Oleandra pistillaris (Sw.) C.Chr. (Oleandraceae) were used as outgroups, following Schneider et al. (2004). All vouchers and GenBank accessions are listed in the Appendix. Aligned data matrix was deposited in TreeBASE (http://purl.org/phylo/ treebase/phylows/study/TB2:S20420).

\section{Sequence acquisition}

Total DNA was extracted from field-acquired silica gel-dried or fresh tissues, using the Qiagen DNeasy Plant mini kit (Qiagen Inc., Valencia, CA, USA). PCR amplifications were performed for two chloroplast genome regions: $r b c \mathrm{~L}$ (coding region; ca. 1,300 bp) and $r p s 4$ (the coding region $r p s 4$ and the intergenic spacer rps4-trnS; ca. 1,100 bp). Amplifications were done in a single reaction with primers $1 \mathrm{~F}$ and $1365 \mathrm{R}$ for the $r b c \mathrm{~L}$ region (Haufler and Ranker 1995) and primers rps5F (Nadot et al. 1995) and trnSR (Smith and Cranfill 2002) for the rps4 and rps4-trnS regions. These regions have shown their utility for inferring phylogenetic relationships in Polypodiaceae, as shown in Janssen and Schneider (2005), Janssen et al. (2007), Kreier and Schneider (2006), Kreier et al. (2007), Kreier et al. (2008), Schneider et al. (2002), Schneider et al. (2004), and Salino et al. (2008).

Polymerase chain reactions were performed in a $20 \mu \mathrm{L}$ solution containing 1.0 $\mu \mathrm{L}$ of non-diluted genomic DNA template, $2.0 \mu \mathrm{L}$ of PCR buffer (Qiagen $10 \times$ PCR Buffer), $1.0 \mu \mathrm{L}$ of DMSO, $1.0 \mu \mathrm{L}$ of BSA $(4 \mathrm{mg} / \mathrm{mL}), 0.8 \mu \mathrm{L}$ of dNTPS $(10 \mathrm{mM}), 0.32$ $\mu \mathrm{L}(10 \mu \mathrm{M})$ of each primer, 0.12 units of Taq Dna polymerase (Qiagen, 5 units $\mu \mathrm{L}$ ), and $14.44 \mu \mathrm{L}$ of ultra-pure water. Thermal cycling conditions were the same for both regions: $3 \mathrm{~min}$ at $94^{\circ} \mathrm{C}, 35$ cycles of $45 \mathrm{~s}$ at $94^{\circ} \mathrm{C}, 60 \mathrm{~s}$ at $53^{\circ} \mathrm{C}$ and $90 \mathrm{~s}$ at $72^{\circ} \mathrm{C}$, followed by $5 \mathrm{~min}$ at $72^{\circ} \mathrm{C}$. Amplicons were purified by precipitation with polyethylene glycol (PEG) and sequenced by Macrogen (Seoul, South Korea) in a bidirectional sequencing reaction in an $\mathrm{ABI} 3730 \mathrm{XL}$.

\section{Alignment and phylogenetic analyses}

Sequence electropherograms were edited using the STADEN package software (Bonfield et al. 1995). Edited sequences were submitted to automated alignment with MUSCLE (Edgar 2004) and the resulting alignment was checked manually using MEGA 7 (Kumar et al. 2016). 
Datasets were analyzed using maximum likelihood (ML) and Bayesian inference (BI). Maximum likelihood was performed using IQ-TREE (Nguyen et al. 2015) with partitioned matrix (Chernomor et al. 2016), automatic selection of the bestfit substitution model (using Bayesian Information Criterion, Schwarz 1978), and branch support assessed with 10,000 ultrafast bootstrap replicates (Minh et al. 2013). Best-fit models according to BIC were TIM2e+G4 for $r b c \mathrm{~L}, \mathrm{~K} 3 \mathrm{Pu}+\mathrm{G} 4$ for $r p s 4$ gene and TVM+G4 for $r p s 4-t r n S$ IGS. For BI, a model-based phylogenetic analysis using Markov chain Monte Carlo-based was performed using MrBayes v3.2.2 (Ronquist et al. 2012), treating each DNA region ( $r b c \mathrm{~L}, r p s 4$ gene and $r p s 4-t r n S$ IGS) as separate partitions. An evolutionary model for each DNA region was selected in jModelTest 2 (Darriba et al. 2012; Guindon and Gascuel 2003), using the Bayesian Information Criterion (Schwarz 1978, Table 1). For the $r b c \mathrm{~L}$ dataset, the SYM+I+G was selected, and for the rps4 gene and rps4-trnS datasets the GTR+G model was selected. Each analysis consisted of two independent runs with four simultaneous Markov Chains run for 5,000,000 metropolis-coupled generations, starting with random initial trees and sampling one tree every 1000 generations. To improve swapping of chains the temperature parameter for heating the chains was lowered to 0.05 . To check the convergence of the runs, ESS (effective sample size) and PSRF (potential scale reduction factor) were examined (Ronquist et al. 2012) using Tracer v.1.6 (Rambaut et al. 2014). Based on the sampled parameter values examined, 2000 trees, including the ones generated during the burn-in phase, were discarded. Remaining trees were used to assess topology and posterior probabilities (PP) in a majority-rule consensus tree. Because PP in Bayesian analysis are not equivalent to bootstrap (BP) (Erixon et al. 2003), we used criteria similar to a standard statistical test, considering groups with $\mathrm{PP}>95 \%$ as strongly supported, PP 90-95\% as moderately supported and PP < $90 \%$ as weakly supported. Results were summarized on a majority rule consensus tree.

\section{Taxonomic studies and conservation status}

Taxonomic conclusions were based on the study of specimens from the following herbaria: BHCB, BM, BR, G, GH, K, LPB, M, MO, NY, P, Q, QCA, QCNE, QPLS, US, USM, and USZ. Specimens with barcode are cited with herbarium acronym followed by barcode number. Abbreviation of genera and species followed IPNI (ipni. org) and morphological terms follow Lellinger (2002). Scanning electron microscope (SEM) images were made using a FEI Quanta 200 SEM, with an accelerating voltage of $30 \mathrm{kV}$. Samples were sputter-coated with gold and imaged digitally. Spore terminology follows Tryon and Lugardon (1991). Conservation status was assessed using IUCN Red List Categories and Criteria (IUCN 2016) to calculate the Extent of Occurrence (EOO) and the Area of Occupancy (AOO), using the GeoCAT tool (Bachman et al. 2011). The specimens that did not present coordinates were attributed one, whenever locality information was available. A grid cell of $10 \mathrm{~km}^{2}$ was used for AOO estimation. 
Table I. Selected models and parameter values for data partitions used in this study.

\begin{tabular}{|c|c|c|c|c|c|c|c|c|c|}
\hline \multirow[b]{2}{*}{ Region } & \multicolumn{5}{|c|}{ Base frequencies } & & & & \\
\hline & \begin{tabular}{|c|} 
Selected \\
model
\end{tabular} & A & C & G & $\mathbf{T}$ & & & & \\
\hline rps4 gene & GTR+G & 0.3204 & 0.1924 & 0.1964 & 0.2908 & & & & \\
\hline rsp4-trnS IGS & $\mathrm{GTR}+\mathrm{G}$ & 0.3249 & 0.1545 & 0.1605 & 0.3601 & & & & \\
\hline \multirow[t]{3}{*}{$r b c \mathrm{~L}$} & $\mathrm{SYM}+\mathrm{I}+\mathrm{G}$ & - & - & - & - & & & & \\
\hline & \multicolumn{9}{|c|}{ Substitution model (rate matrix) } \\
\hline & A-C & A-G & A-T & C-G & C-T & G-T & Ti/tv & I & G \\
\hline rps4 gene & 0.7965 & 3.5099 & 0.1724 & 0.4720 & 3.0330 & 1 & 0 & 0 & 0.9640 \\
\hline$r s p 4-t r n S$ IGS & 0.9825 & 2.7675 & 0.2147 & 0.7566 & 2.9398 & 1 & 0 & 0 & 0.5615 \\
\hline$r b c \mathrm{~L}$ & 1.9337 & 8.1010 & 1.1861 & 0.8284 & 11.3400 & 1 & 0.5474 & 0 & 0 \\
\hline
\end{tabular}

\section{Results}

The final combined dataset presented 2339 bp, 599 from rps 4 gene, 473 from the rps4trnS IGS, and 1267 from $r b c \mathrm{~L}$. All analyses recovered the main polygrammoid clades found by Schneider et al. (2004; see Fig. 1): the loxogrammoid clade (1.00 PP, 100\% $\mathrm{BS})$, the drynarioid + selligueoid clade $(0.91 \mathrm{PP}, 71 \% \mathrm{BS})$, the platyceroid-microsoroid clade (1.00 PP, $100 \% \mathrm{BS})$, and a clade comprising neotropical representatives (0.62 PP, 84\% BS).

Inside the neotropical clade, Synammia appears as sister to all the other neotropical clades, a result also obtained by Schneider et al. (2006) (Fig. 1). Sister to Synammia, our analyses recovered three main clades: the polypodioid clade including Pecluma, Phlebodium, Pleopeltis, and Polypodium s.s. (1.00 PP, 70\% BS,), the campyloneuroid clade, containing Campyloneurum, Microgramma, and Niphidium (1.00 PP, 95\% BS), and a clade (1.00 PP, 99\% BS) that included the grammitid ferns (1.00 PP, 100\% BS), Serpocaulon (1.00 PP, 100\% BS), and Polypodium chrysolepis (1.00 PP, 100\% BS). Both maximum likelihood and Bayesian inference hypotheses recovered $P$. chrysolepis as sister to Serpocaulon (0.91 PP, 88\% BS).

\section{Discussion}

The polygrammoid topology recovered in our analyses agrees with previous results from several studies (Schneider et al. 2004, Schneider et al. 2006, Smith et al. 2006b, Salino et al. 2008, Otto et al. 2009). The placement of Polypodium chrysolepis as an isolated lineage inside neotropical Polypodiaceae and closely related to Serpocaulon and the grammitid ferns (1.00 PP, 97\% BS) confirms results previously found by Schneider et al. (2004); this species is not part of the campyloneuroid clade, containing Microgramma, nor does it belong to the polypodioid clade, containing Polypodium s.s. and Pleopeltis. The afore-mentioned genera have all been used as a "home" for Polypodium chrysolepis by various authors in the past (e.g., Hooker 1844, de la Sota 1960, Crabbe 1967). 


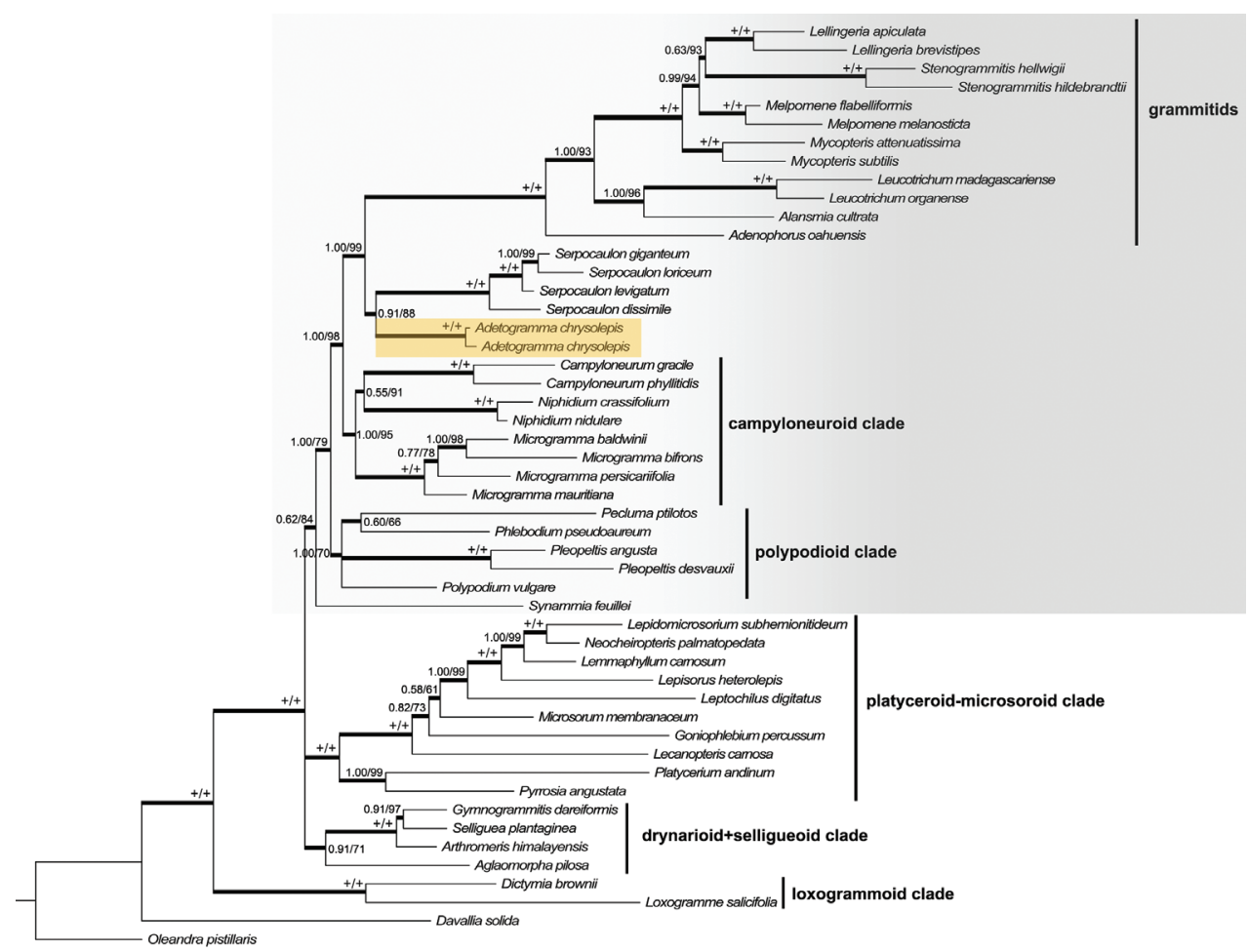

Figure I. Majority rule consensus tree resultant from Bayesian inference analyses from combined $r b c \mathrm{~L}$ and $r p s 4$ datasets. Values above branches nodes correspond to Bayesian posterior probabilities and maximum likelihood bootstrap support, respectively. +/+ indicates with $1.00 \mathrm{PP}$ and 100\% BS support. Clades cited in text follow Schneider et al. (2004); gray shade indicates neotropical Polypodiaceae. Adetogramma chrysolepis is highlighted in orange.

In our analyses, Serpocaulon, a group segregated from Polypodium (Smith et al. 2006a), appears as sister to P. chrysolepis (0.97 PP, 88\% BS), supporting the results of Schneider et al. (2004). Morphologically Polypodium chrysolepis can be readily distinguished from Serpocaulon by having free veins, non-clathrate scales, peltate scales covering the laminar surfaces, and peltate scales as paraphyses. These characters contrast with features of Serpocaulon species: regular anastomosing veins (goniophlebioid venation), clathrate scales, and the absence of scales in veins or laminar surface between veins or paraphyses, or if paraphyses are present, they are 2-3 celled glands (Smith et al. 2006a) (Table 2). Hernández et al. (2014) reported similarities in anatomical features of root cortical cells between P. chrysolepis and Serpocaulon gilliesii (C.Chr.) A.R.Sm, the only Serpocaulon species sampled in their study. Of all Serpocaulon species, S. levigatum (Cav.) A.R.Sm. is the only one that has entire leaves, and therefore the single species resembling $P$. chrysolepis morphologically. However, in addition to the characteristics mentioned above, S. levigatum differs from $P$. chrysolepis by having multiple rows of sori on each side of midvein and by rhizomes be- 
ing covered by whitish wax-like deposits, with few roundish scales, not covering the entire surface of the rhizome (Smith et al. 2006a, Labiak and Prado 2008), while in P. chrysolepis only one row of sori is found on each side of midvein, and rhizomes lack whitish wax-like deposits and are covered by lanceolate rhizome scales (Figs 2, 3). Smith et al. (2006a) highlighted a possible trend of increasing pinnation in Serpocaulon, but the fact their results showed $S$. levigatum to be closely related to species with completely free, non-adnate pinnae would make the entire lamina shared with P. chrysolepis a homoplastic feature.

Sanín $(2014,2015)$ described a species of Serpocaulon with free veins (S. tayronae D.Sanín), but no phylogenetic evidence is presented to support its placement in Serpocaulon. Sanín also stated that S. eleuterophlebium (Fée) A.R.Sm. and S. patentissimum (Mett.) A.R.Sm. have free veins, although Hensen (1990) describes their venation as regularly anastomosing in the taxonomic treatment of the group (treated as the Polypodium loriceum-complex). More evidence is needed to elucidate the generic position of S. obscurinervium and S. tayronae, as is the case with several other groups morphologically related to Polypodium (Tejero-Díez 2005, Assis et al. 2016).

Polypodium chrysolepis was combined by Crabbe (1967) in Microgramma, but it exhibits morphological characters distinct from that genus. It has free venation while Microgramma, as circumscribed by Almeida et al. (unpublished data) and Salino et al. (2008), has anastomosing veins on the sterile fronds. Moreover, P. chrysolepis has lanceolate, peltate, long-stalked paraphyses (Fig. 2E) while in Microgramma, paraphyses (if present) are hairlike or lanceolate and sessile, never stalked (Table 2). Polypodium chrysolepis resembles some Pleopeltis species in having entire laminae, long-creeping rhizomes, and peltate paraphyses. The main difference between Pleopeltis and Polypodium chrysolepis lies in the shape of the paraphyses - ovate-lanceolate in P. chrysolepis vs. roundish in Pleopeltis. Furthermore, species of Pleopeltis with entire blades always have anastomosing veins (Table 2).

Grammitid ferns, the lineage sister to the Polypodium chrysolepis+Serpocaulon clade, are a very distinct group of species inside the polygrammoid ferns. Once recognized as a separated family (Parris 1990) or a subfamily inside Polypodiaceae (Tryon and Tryon 1982), this lineage can be distinguished by usually tetrahedral chlorophyllous spores, sporangia stalk reduced to a single cell wide in the middle, absence of scales in the fronds, and free or occasionally anastomosing without free included veinlets (Parris 1990, Sundue et al. 2010). Although sharing the free veins with Polypodium chrysolepis, we can distinguish the latter from grammitids by the bilateral spores, and the presence of scales in the blades (Table 2).

Polypodium s.s., following Tejero-Díez (2005), includes the species groups of Polypodium plesiosorum, Polypodium colpodes, Polypodium dulce (sensu Moran 1995) and Polypodium vulgare species group (sensu Haufler et al. 1995). Using this circumscription, Polypodium s.s. remains a polyphyletic assemblage of species, with species from the Polypodium dulce complex apparently closer to Pecluma than to Polypodium s.s. (Otto et al. 2009, Assis et al. 2016); in fact, some species in this group were moved to Pecluma (Assis et al. 2016). Further studies are needed to define a monophyletic 


\begin{tabular}{|c|c|c|c|c|c|c|c|c|}
\hline 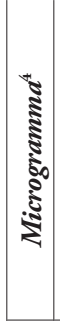 & 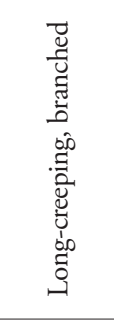 & 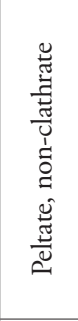 & 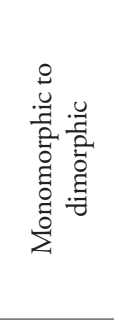 & 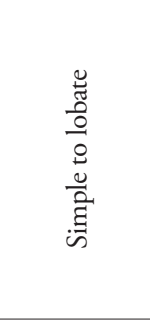 & 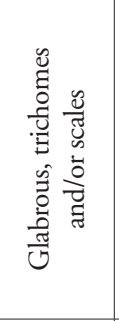 & 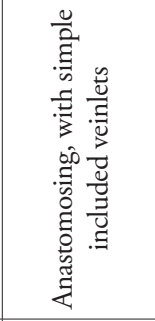 & 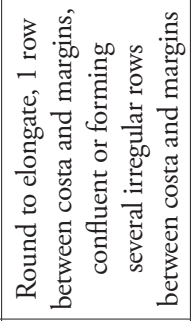 & 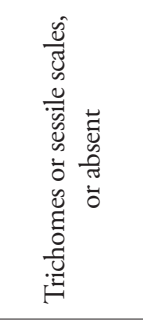 \\
\hline 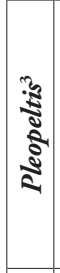 & 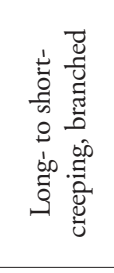 & 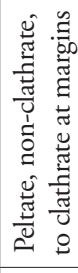 & 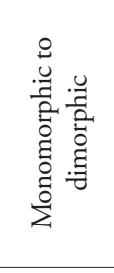 & 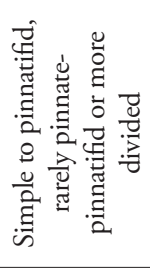 & $\begin{array}{l}\text { है } \\
\text { लू }\end{array}$ & 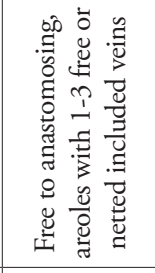 & 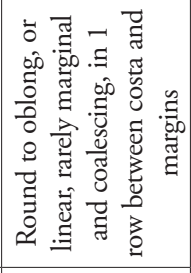 & 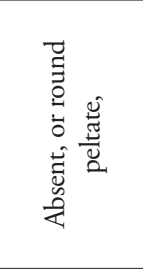 \\
\hline 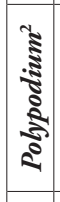 & 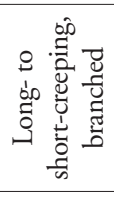 & 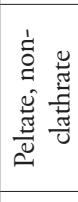 & 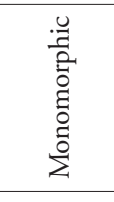 & 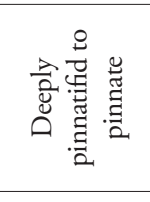 & 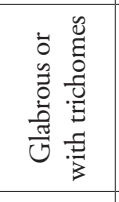 & 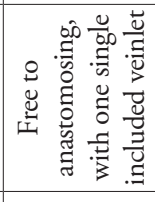 & 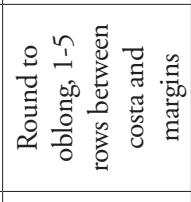 & 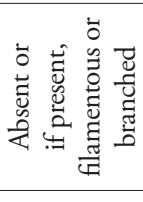 \\
\hline 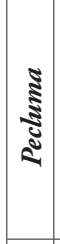 & 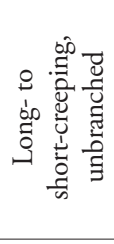 & 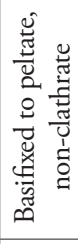 & 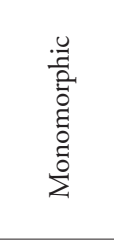 & 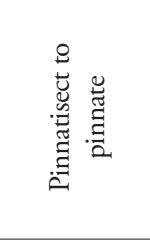 & 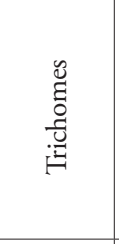 & 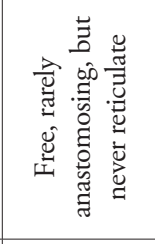 & 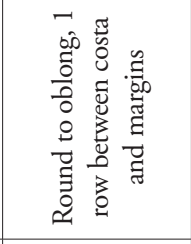 & 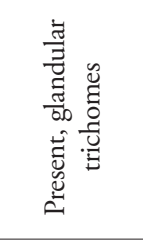 \\
\hline : & 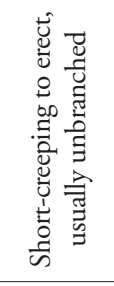 & 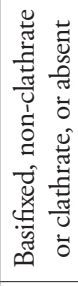 & 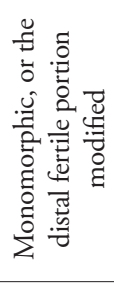 & 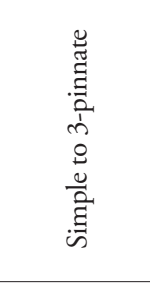 & 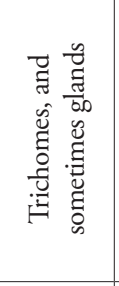 & 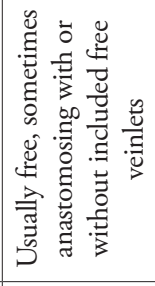 & 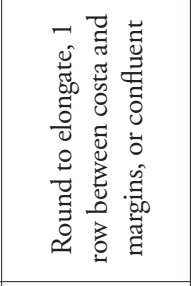 & 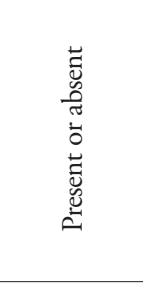 \\
\hline מี & 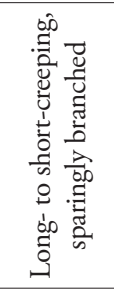 & 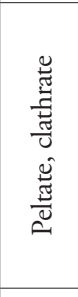 & 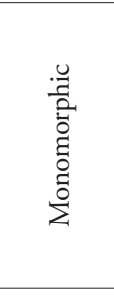 & 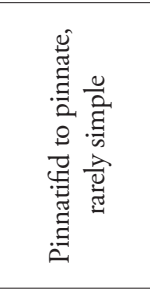 & 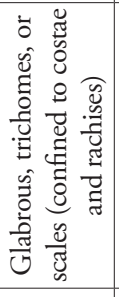 & 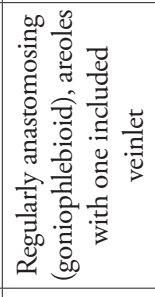 & 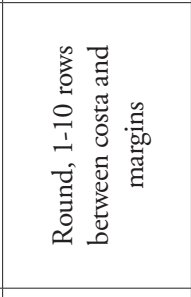 & 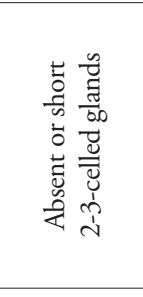 \\
\hline 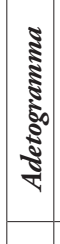 & 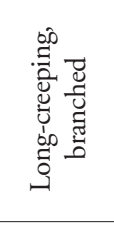 & 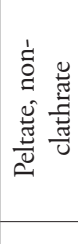 & 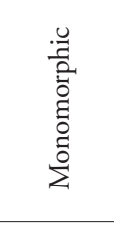 & 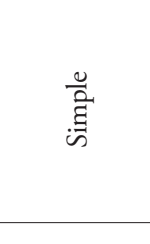 & డే & 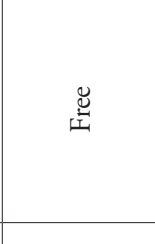 & 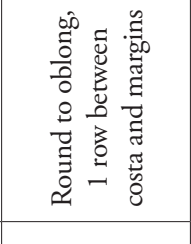 & 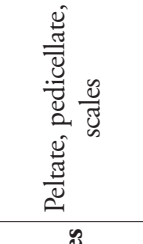 \\
\hline & 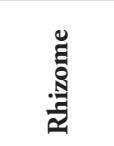 & 苛 & 总 & 氙 & 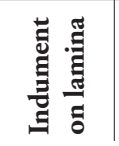 & & फे & 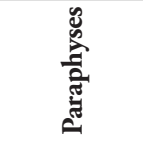 \\
\hline
\end{tabular}




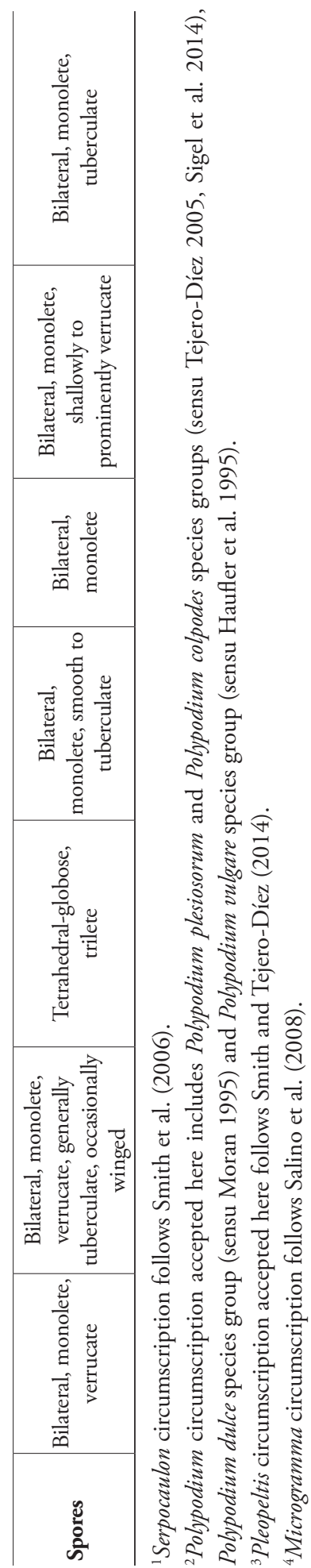


Polypodium. Nevertheless, following this circumscription, Polypodium s.s. can be distinguished from $P$. chrysolepis by its deeply-pinnatifid to pinnate leaves with free (in the Polypodium dulce complex species) to anastomosing veins, with a single included veinlet in each areole. Indument is also a useful character for separating $P$. chrysolepis: Polypodium s.s. shows glabrous to pilose laminar surfaces and the paraphyses, when present, are filamentous or branched, while $P$. chrysolepis has scaly laminae and the paraphyses are pedicellate scales. Table 2 summarizes the features and main differences amongst the related genera.

Our results do not support the inclusion of Polypodium chrysolepis in any genus previously recognized, including Microgramma, Pleopeltis, or Polypodium s.s. Therefore, we consider this species as constituting a separated, isolated lineage inside the polygrammoid clade. Because the species also has a morphology distinct from that of all other known genera in Polypodiaceae, we believe it merits recognition as a genus, and is described below.

\section{Taxonomic treatment}

\section{Adetogramma T.E.Almeida, gen. nov.}

urn:Isid:ipni.org:names:77161864-1

Note. Adetogramma is similar to Microgramma and Pleopeltis in its epiphytic habit, long-creeping rhizomes and in having entire leaves with one row of sori on each side of the midrib, but differs from these genera by having free veins (vs. veins anastomosing in Microgramma and Pleopeltis) and peltate, pedicellate, lanceolate paraphyses (vs. hairlike or lanceolate and sessile paraphyses in Microgramma, and round, peltate, pedicellate paraphyses in Pleopeltis).

Type. Adetogramma chrysolepis (Hook.) T.E.Almeida, comb. nov., Polypodium chrysolepis Hook., Icon. Pl. 8: t. 721. 1845.

\section{Adetogramma chrysolepis (Hook.) T.E.Almeida, comb. nov.} urn:Isid:ipni.org:names:77161865-1

Figures 2-4

Lepicystis chrysolepis (Hook.) Diels, Nat. Pflanzenfam. 1(4): 322, f. 167A-B. 1899.

Type: Based on Polypodium chrysolepis Hook.

Microgramma chrysolepis (Hook.) Crabbe, Brit. Fern Gaz. 9: 316. 1967.

Type: Based on Polypodium chrysolepis Hook.

Polypodium bangii Baker, Bull. Misc. Inform. Kew 1901: 145. 1901.

Type: Bolivia. Yungas, 1890, A.M. Bang 734 (lectotype, designated here: BM! [BM000936895]; isolectotypes: B! [B200075587], BR!, GH!, K! [K000590773], LE!, MO! [MO5472871)], NY! [NY00144786, NY00144787], US! [US00065725]). 
Basionym. Polypodium chrysolepis Hook., Icon. Pl. 8: t. 721. 1845.

Type. Ecuador. Andes de Quito, W. Jameson 37 (wrongly typed in protologue as “73"; lectotype, designated by Tryon et al., 1993, pg. 151: K! [K000590772]; isolectotypes: BM! [BM000936896], G!, FI [FI004543!]).

Plants epiphytic or epipetric, rarely terrestrial. Rhizomes long-creeping, branched, 0.6-0.9 mm wide, cylindrical, with four vascular bundles; short, perpendicular roots about 5-20 mm long, these regularly spaced, covered with brownish root hairs; rhizome scales 4.3-7.1 mm long, peltate, not clathrate, linear-lanceolate, with elongate cells, the margins entire from the base to the middle and toothed beyond the middle, with 1- or 2-celled marginal teeth, scales concolorous, stramineous and usually darker at the attachment point. Fronds remote, $2.2-4.5 \mathrm{~mm}$ apart, articulate, monomorphic. Stipes nearly absent to $55 \mathrm{~mm}$ long, $0.4-0.7 \mathrm{~mm}$ in diameter, covered with sparse peltate, lanceolate, sessile, non-clathrate, concolorous, stramineous scales, these 1.4-3.5 $\mathrm{mm}$ long, darker at the attachment point; phyllopodia darker than stipes. Laminae light green, $5.0-17.0 \times 1.0-2.5 \mathrm{~cm}$, simple, chartaceous, linear-lanceate to lanceolate, bases acuminate to attenuate, decurrent in the distal third of the stipe, apices acute to obtuse, laminar surfaces squamose on both sides, scales lanceolate, peltate, sessile, non-clathrate, concolorous, translucent, stramineous, darker at attachment point, slightly erose at bases and entire at apices, scales present also on abaxial and adaxial sides of costae and veins, and on the laminar margins, 1.3-2.6 mm long. Veins free, immersed, obscure, 1-2 furcate, not reaching laminar margins, midribs and lateral veins immersed on both sides of the laminae, not evident. Sori superficial, rounded to oblong, 1.6-2.6 × 1.9-5.0 mm, terminal to subterminal on veins, receptacles elongate, sporangia long-stalked, paraphyses present, scale-like, similar those of the laminar surfaces, peltate, pedicellate, with pedicels as long as those of the sporangia, paraphyses completely covering immature sori. Spores yellow, with verrucate surfaces.

Distribution and ecology. Restricted to central and southern Andes, with known collections from Ecuador, Peru, Bolivia, and Argentina (Fig. 5). It occurs preferably in high elevation formations, ranging from 1,800 to 4,100 meters above sea level, with most collections between 3,000-4,000 $\mathrm{m}$ in the central part of the Andes, but found at lower elevations further south in Southern Bolivia and Argentina. Adetogramma chrysolepis is mostly epiphytic or epipetric, rarely terrestrial. Epiphytic specimens usually grow on Polylepis, Berberis, or Buddleja, inside highland humid montane forests (Yungas). Epipetric ones were recorded as growing on rocks inside Yungas forest or in sub-alpine grasslands with scattered shrubs, normally associated with mosses (de la Sota 1960). According to herbarium sheet labels, the species also occurs in secondary forests and modified areas.

Conservation status. Least Concern (LC - IUCN 2016). Adetogramma chrysolepis presents $\mathrm{EOO}$ of $1,108,559.773 \mathrm{~km}^{2}$ and $\mathrm{AOO}$ of $5,300 \mathrm{~km}^{2}$, respectively, and its conservation status is considered Least Concern. However, the species occurs in a fragile environment that is undergoing an increasing pressure due to human settlement, and extensive grazing by cattle and camelids. Although it is known from at least 40 localities and occurs in several protected areas (e.g., Parque Nacional Carrasco, Cocha- 


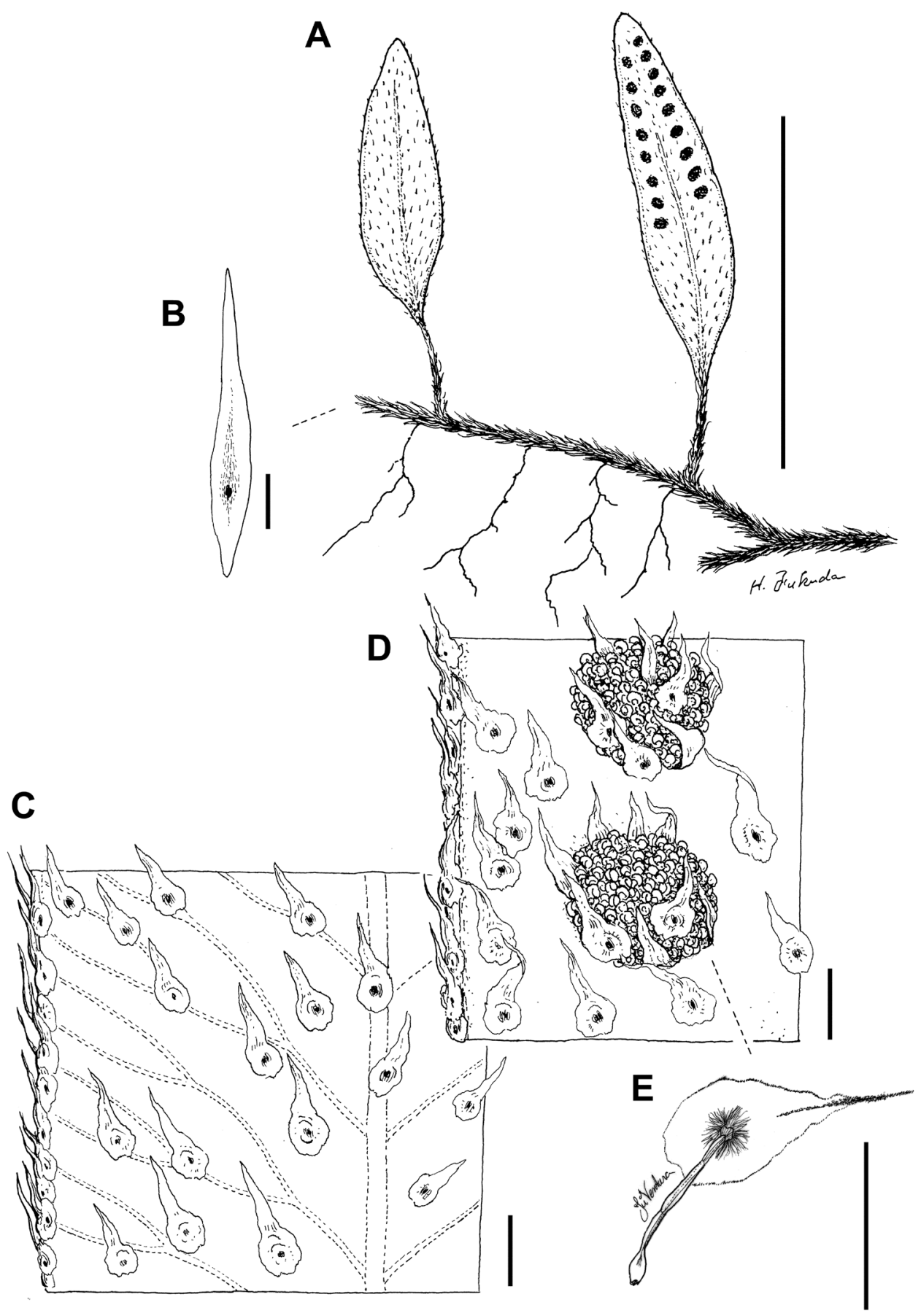

Figure 2. Adetogramma chrysolepis (Hook.) T.E.Almeida. A Habit B Rhizome scale C Sterile lamina detail showing free venation and laminar scales $\mathbf{D}$ Fertile lamina detail showing sori, paraphyses, and laminar scales E Paraphysis detail. Drawings A-D by H. Fukuda from Dorr et al. 6764 (NY); drawing E by Juliana Ventura from T.E. Almeida \& L.L. Giacomin 3121 (BHCB). Scale bars: A $=5 \mathrm{~cm}, \mathbf{B}-\mathbf{E}=1 \mathrm{~mm}$. 

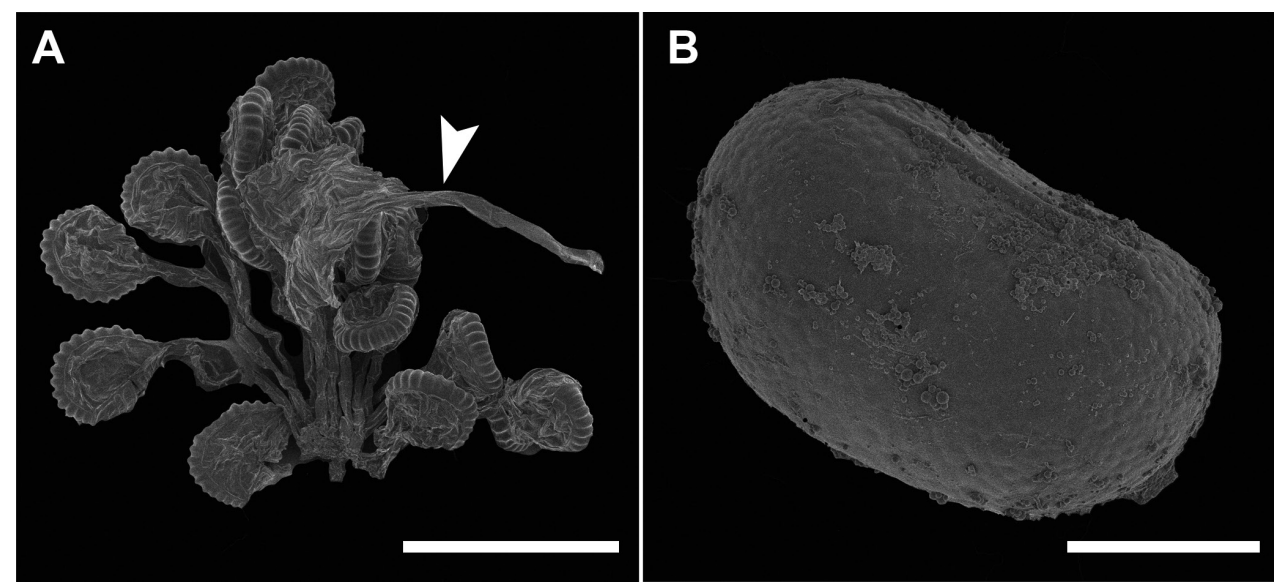

Figure 3. Adetogramma chrysolepis (Hook.) T.E.Almeida. A, B Scanning electron micrography (SEM); magnification $75 \times$ and $1750 \times$, respectively $\mathbf{A}$ Sori showing sporangia and paraphysis (the latter indicated by an arrow head) B Spores. Images from Almeida \& Giacomin 3121 (BHCB). Scale bars: $\mathbf{A}=500 \mu \mathrm{m}$, $\mathbf{B}=20 \mu \mathrm{m}$.

bamba, Bolivia; Reserva Nacional de Flora e Fauna de Tariquía, Tarija, Bolivia; Parque Nacional Huascarán, Ancash, Peru; Santuario Nacional de Ampay, Apurimac, Peru; Parque Nacional del Rio Abiseo, San Martín, Peru) no information on population fluctuations is available. Decline in the quality and area of occupancy in the near future seems feasible and it is advised that the species be monitored.

Etymology. The generic epithet refers to the most distinctive character of the species, the free venation (Fig. 2C); from the Greek adetos-, free and -gramma, line.

Notes. Adetogramma is a monotypic genus, and although its sole species, $A$. chrysolepis, varies in laminar size and shape and stipe length, all other characters, such as the rhizome and stipe scales, venation, and paraphyses, are constant. Specimens from the Argentinean Provinces of Tucumán and Salta and Bolivian Provinces of Tarija and Chuquisaca have very long, linear laminae, and longer stipes, but in other characters are congruent with the circumscription here adopted for $A$. chrysolepis. This variation may reflect colonization of drier, seasonal habitats in a subtropical region.

Morphologically, Adetogramma chrysolepis shares features with several neotropical genera of Polypodiaceae (Table 2), while presenting unique characteristics within the group. Free veins (Figs 2C, 4C) are shared with the Polypodium dulce species group, some Pecluma species, a few Pleopeltis species, few pinnatisected species of Serpocaulon, $S$. tayrona and most grammitids. Presence of peltate scales on the receptacle is shared between Adetogramma and Pleopeltis (Figs 2D-E, 3A, 4A-B). In both genera, paraphyses may almost completely cover the sporangia in immature sori, and presumably have a protective function.

Kreier et al. (2008) hypothesized that Serpocaulon, sister group to Adetogramma, has the Bolivian Andes and adjacent southeastern Brazil as its ancestral area. According to this hypothesis, the Bolivian Andes formed a path for migration and successful colo- 
nization of the Northern Andes, with subsequent migration into Central America and Caribbean regions. With Adetogramma as sister to Serpocaulon, we believe the hypothesis of the Bolivian Andes as putative ancestral area of the Adetogramma+Serpocaulon clade common ancestor to be more likely. From Bolivia, Adetogramma could have dispersed southwards where colder climate allowed it to colonize lower elevation habitats, and also migrated northwards to Peru and Ecuador. Adetogramma chrysolepis may represent a single relictual species from a previously more diverse and geographically widespread group, or a single, undiversified lineage that colonized high elevation environments. More detailed phylogenetic or phylogeographic studies are required to support or refute these hypotheses.

Specimens examined. ARGENTINA. Jujuy: San Antonio, 27 Apr 2015, C. Martín 479 (SI); Valle Grande, 14 Apr 2016, C. Martin 730 (SI). Salta: Salta, 21 Nov 1945, S.A. Pieroff 1326 (NY!); Santa Victoria, 05 Dec 2015, C. Martín 673 (SI). Tucumán: s.l., 1952, H. Brücher s.n. (LP!); s.l., s.d., L. Castillón 2248 (BM!); s.l., s.d., M. Lillo 11534 (BM!, GH!, K!, NY!); La Ventanita, s.d., M. Lillo 16713 (BM!, GH!, K!); Burruyacu, 20 Jan 1947, Borsini s.n. (LP!); Chicligasta, 11 Dec 1925, S. Venturi 4062 (BM!, GH!); idem, 13 Feb 1924, S. Venturi 3151 (GH!); Tafi del Vale, Jan 1912, L. Castillón 35 (BM!, GH!, K!, LP!, NY!). BOLIVIA. Chuquisaca: Hernando Siles, 09 Nov 2007, J. Villalobos 928 (MO!, UC). Cochabamba: Ayopaya, 07 May 1990, E. Hennipman 8148 (LPB!); idem, 28 Oct 2007, J. Terán 1486 (MO!); idem, 30 Oct 2007, J. Terán 1563 (MO!); Carrasco, 20 Mar 1991, I. Hensen 1819 (LPB!); idem, 25 Feb 1996, M. Mercado 501 (MO!); Chapare, 30 Sep 2001, J.R.I. Wood 17271 (LPB!); Cochabamba, 27 Jan 1950, W.M.A. Brooke 6081 (BM!, NY!); Jose Carrasco Torrico, 27 Jun 1996, M. Kessler 6763 (NY!, UC); idem, 02 Jul 1996, M. Kessler 6877 (NY!, UC); Tiraque, 10 May 2005, E. Zurita 390 (MO!). La Paz: Bautista Saavedra, 27 Apr 1993, P. Gutte 559 (LPB!); Franz Tamayo, 24 Feb 2008, A.F. Fuentes Claros 11982 (MO!, UC); idem, 04 Mar 1980, J. Krach 9207 (LPB!); idem, 06 Apr 2009, M.I.L. Rivera 599 (MO!); Inquisivi, 21 Dec 1989, L.J. Dorr 6764 (LPB!, NY!); idem, 18 Feb 1989, M.A. Lewis 35242 (LPB!, MO!, NY!, UC); idem, 09 Mar 1991, M.A. Lewis 38230 (MO!); idem, 04 Sep 1991, M.A. Lewis 39744 (F, GH!, LPB!, MO!); Larecaja, 1818, G. Mandon 1560 (BM!, G!, K!, NY!); Murillo, 16 May 1985, J.C. Solomon 13742 (LP!, LPB!, MO!, NY!); Nor Yungas, XI/1900, O. Buchtien 2751 (P!); idem, 07 Mar 1969, H. Doppelbaur s.n. (MO!); Pedro Domingo Murillo, 17 Mar 2012, T.E. Almeida 3121 (BHCB!, LPB!); Pongo, s.d., W.M.A. Brooke 5456 (BM!, NY!); Unduavi, 1890, A.M. Bang 734 (B!, BR!, GH!, K!, LE!, MO!, US!); idem, 30 Mar 1977, J.D. Boeke 1375 (NY!); idem, Feb 1914, O. Buchtien 420 (B!, BM!, G!, GH!, K!, NY!, P!); idem, 19 Jun 1912, E. Rosenstock 49 (B!, P!). Santa Cruz: Manuel M. Caballero, 11 Apr 2004, $R$. Nuñez Cabrera 682 (MO!, NY!, UC, USZ!); idem, 08 Mar 2012, T.E. Almeida 3083 (BHCB!, HSTM!, LPB!); s.l., 26 Oct 1928, J. Steinbach 8531 (BM!, GH!, K!, MO!, NY!). Tarija: Aniceto Arce Ruiz, 13 Jun 2004, I. Jimenez 2420 (NY!, UC); Arce, 10 Nov 2004, H. Huaylla 1509 (MO!); idem, 27 Jun 2005, H. Huaylla 1882 (MO!); idem, 12 Nov 2004, M. Serrano 5082 (MO!); idem, 12 Nov 2004, M. Serrano 5136 


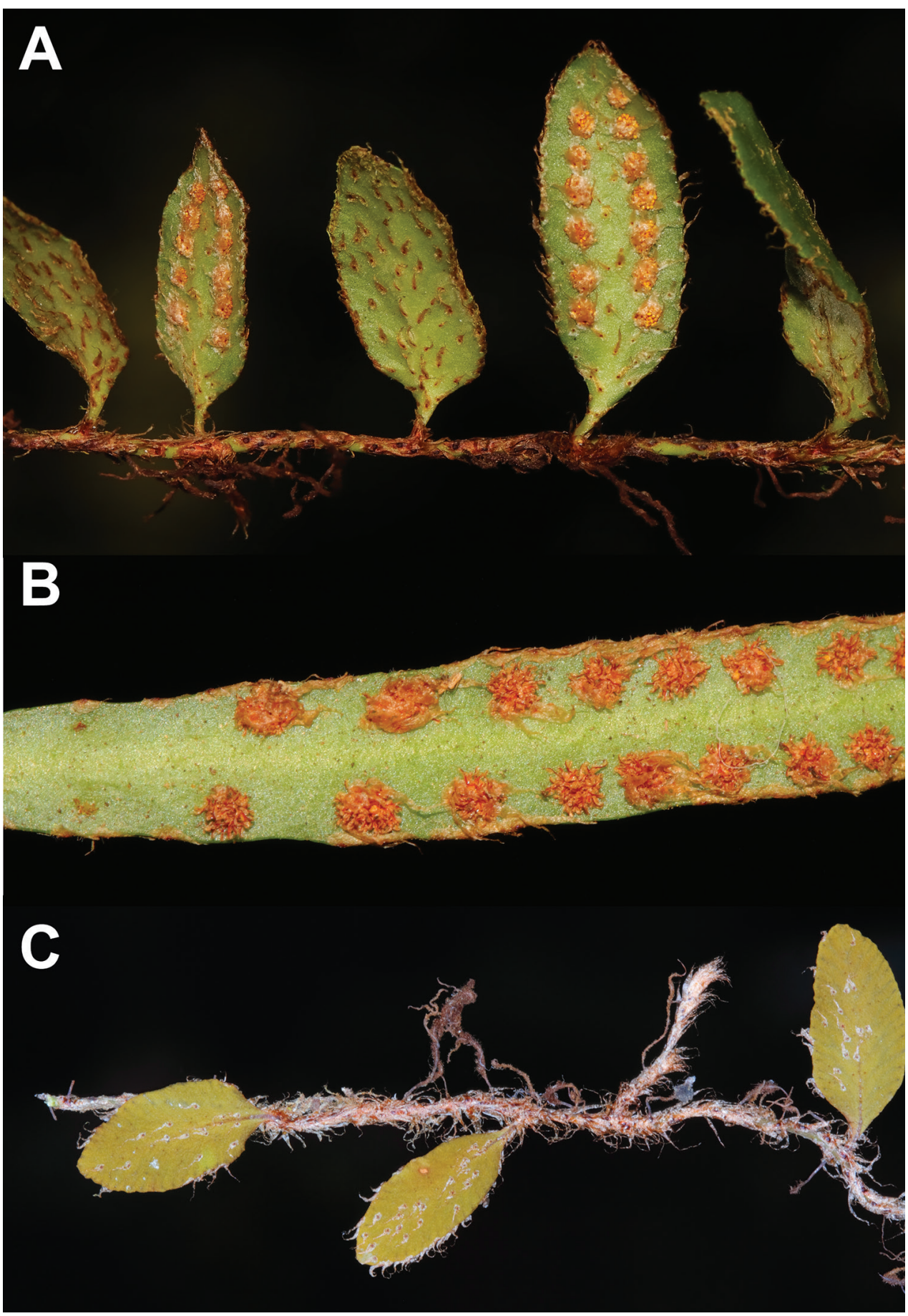

Figure 4. Adetogramma chrysolepis (Hook.) T.E.Almeida. A Fertile and sterile fronds B Detail of abaxial surface of fertile frond, showing laminar scales and paraphyses $\mathbf{C}$ Juvenile sterile leaves. (A) and (B) from C. Martín 730 (SI), (C) from C. Martín 479 (SI). 


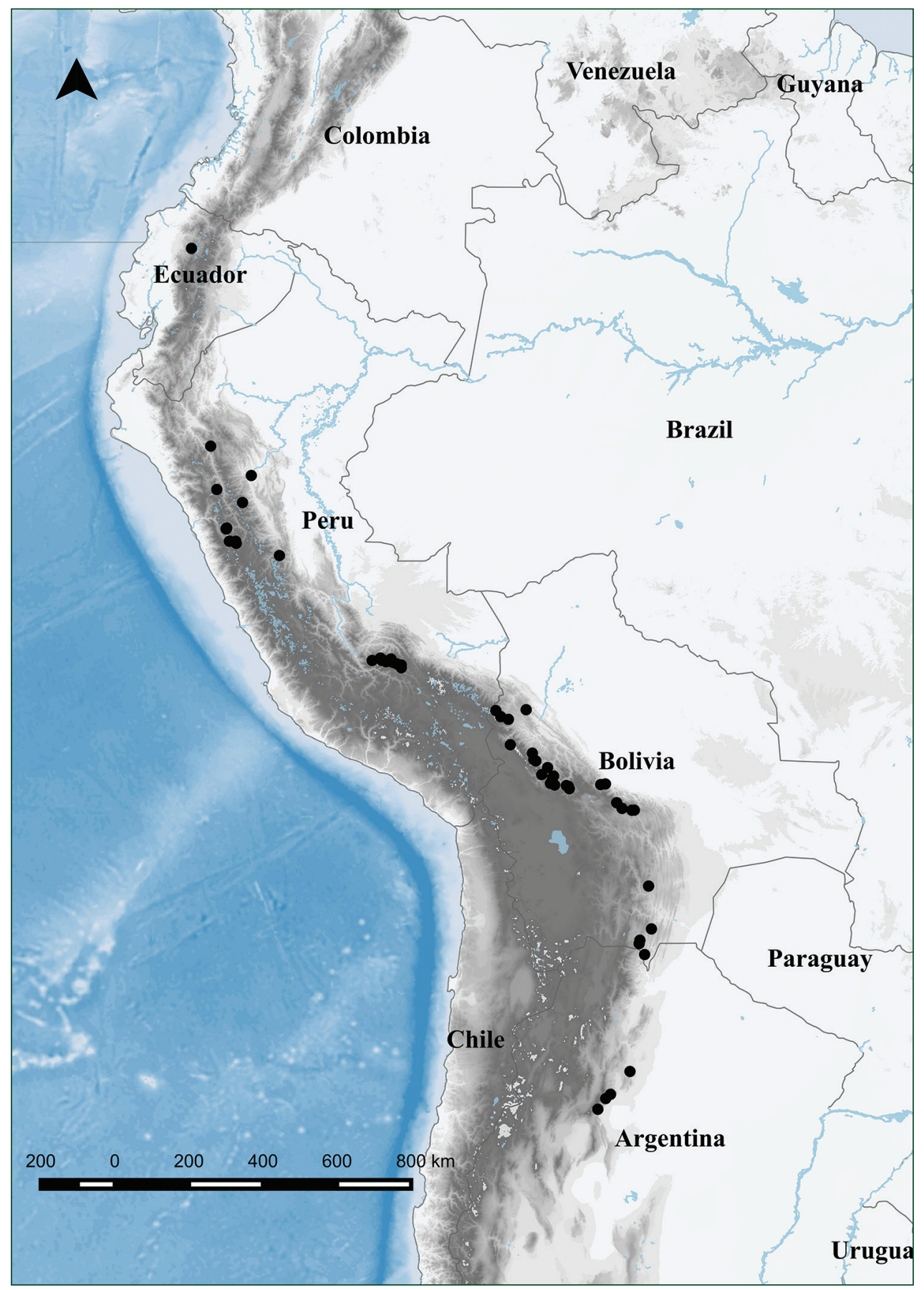

Figure 5. Distribution of Adetogramma chrysolepis. 
(MO!); idem, 03 Feb 2005, M. Serrano 5945 (MO!); O’Connor, 22 Oct 1983, S. G. Beck 9651 (LPB!); s.l, s.d., M. Cárdenas 1036 (GH!); s.l., 07 Mar 1969, H. Doppelbaur 291 (M!); s.l., 06 May 1928, [illegible] 1569 (B!); s.l., 21 Aug 1926, [illegible] 2559 (B!). ECUADOR. Pichincha: Quito, s.d., W. Jameson 73 (G!, K!). PERU. Amazonas: s.l., 03 Aug 1962, J.J. Wurdack 1592 (GH!). Ancash: Carhuaz, 14 Feb 1985, D.N. Smith 9571 (MO!, USM); idem, 18 Jul 1985, D.N. Smith 11264 (BM!, ENAG, F, GH!, MICH, MO!, NY, UC, USM); Huari, 08 May 1986, D.N. Smith 12415 (BM!, F, LPB!, MO!, NY, UC); idem, 13 Jun 1986, Smith 12648 (MO!); Yungay, 13 Jan 1985, Smith 9150 (GH!, MO!, USM); idem, 17 Apr 1985, D.N. Smith 10326 (MO!, USM); idem, 19 Apr 1985, D.N. Smith 10463 (MO!, USM). Apurimac: Abancay region, Oct 1935, students of Santander C. s.n. (UC); Abancay, Tamburco, 6 Jun 2015, V. Zuñiga 452 (USM). Cusco: s.l., 31 May 2002, W.L. Galiano 4034 (MO!); s.l., 14 Feb 1987, P.Núnez Vargas 6988 (MO!); s.l., 10 Jun 2002, L.Valenzuela Gamarra 238 (NY!, MO!); La Convención, 11 Jul 2003, E. Bonino 832 (MO!); idem, 23 Jul 2003, E. Bonino 909 (MO!, UC); idem, 26 Mar 2004, I. Huamantupa 4428 (MO!); idem, 21 Sep 2005, I. Huamantupa 6844 (MO!, USM!); idem, 30 Mar 1939, C. Vargas 4505 (MO!); Urubamba, 23 Apr 1982, B. Peyton 51 (MO!); idem, 04 Jul 1982, B. Peyton 766 (MO!); idem, 17 Aug 1982, B. Peyton 1053 (GH!, MO!); idem, 05 Nov 1988, A. Tupayachi 758 (GH!, MO!, NY!); idem, 30 Dec 1963, L. Valenzuela 14983 (GH!). Huánuco: Yanano, 13-16 May 1923 J.F. Macbride 3826 (G!). La Libertad: Pataz, 24 Feb 1986, K. Young 2988 (NY); s.l., 23 Jun 1974, A. López M. 8129 (G!, MO!, NY!). Lambayeque: Ferreñafe, 9 Jun 2012, L. García Llatas s.n. (USM). San Martín: Mariscal Cáceres, Huicungo, 15 Jun 2001, B. León 5249 (NY!, USM).

\section{Acknowledgments}

This work was supported by FAPEMIG (Fundação de Amparo à Pesquisa do Estado de Minas Gerais through grant CRA-APQ 01599-10, CNPq (Conselho Nacional de Desenvolvimento Científico e Tecnológico) through grants 478723/2010-5 and $563568 / 2010$, and for productivity grants, all attributed to AS, and the ATM "Biodiversité actuelle et fossile" of the Muséum national d'Histoire naturelle (2012) attributed to SH. CNPq also provided research scholarships to TEA (555226/2010-7 and 202160/2011-4). We thank the Muséum national d'Histoire naturelle de Paris, France (MNHN), the Service de Systématique Moléculaire (SSM - MNHN) and Céline Bonillo for the support and help. L.L. Giacomin for helping with fieldwork and for carefully reviewing the manuscript. A. Field, A. Smith, B. León, D. Sanín, E. Smidt, J. Prado, J.A.N. Batista, and V.A.O. Dittrich for critical reviews and comments. T. Martínez for guiding us in Bolivia; to the curators of all visited herbaria; Claudia Martín for the pictures, and J.T. Mickel for allowing the use of the drawings. 


\section{References}

Assis FC, Almeida TE, Russell SJ, Schneider H, Salino A (2016) Molecular phylogeny and recircumscription of the fern genus Pecluma (Polypodiaceae-Polypodiopsida). Phytotaxa 247(4): 235-246. http://dx.doi.org/10.11646/phytotaxa.247.4.1

Bachman S, Moat J, de la Torre J, Scott B (2011) Supporting Red List threat assessments with GeoCAT: geospatial conservation assessment tool. ZooKeys 150: 117-126. http://dx.doi. org/10.3897/zookeys.150.2109

Bonfield JK, Smith KF, Staden R (1995) A new DNA sequence assembly program. Nucleic Acids Research 23(24): 4992-4999. http://dx.doi.org/10.1093/nar/23.24.4992

Chernomor O, von Haeseler A, Minh BQ (2016) Terrace aware data structure for phylogenomic inference from supermatrices. Systematic Biology 65(6): 997-1008. http://dx.doi. org/10.1093/sysbio/syw037

Crabbe JA (1967) Bolivian pteridophytes collected by Winifred Brooke. Fern Gazette 9: 309-320.

Darriba D, Taboada GL, Doallo R, Posada D (2012) jModelTest 2: more models, new heuristics and parallel computing. Nature Methods 9: 772. http://dx.doi.org/10.1038/nmeth.2109

de la Sota ER (1960) Polypodiaceae y Grammitidaceae Argentinas. Opera Lilloana 5: 5-229.

Diels L (1899) Polypodiaceae. In: Engler A, Prantl K (Eds) Die Natürlichen Pflanzenfamilien. Wilhelm Engelmann, Leipzig, 139-336.

Edgar RC (2004) MUSCLE: multiple sequence alignment with high accuracy and high throughput. Nucleic Acids Research 32(5): 1792-1797. http://dx.doi.org/10.1093/nar/gkh340

Erixon P, Svennblad B, Britton T, Oxelman B (2003) Reliability of Bayesian posterior probabilities and bootstrap frequencies in phylogenetics. Systematic Biology 52(5): 665-673. http://dx.doi.org/10.1080/10635150390235485

Guindon S, Gascuel O (2003) A simple, fast and accurate method to estimate large phylogenies by maximum-likelihood. Systematic Biology 52(5): 696-704. http://dx.doi. org/10.1080/10635150390235520

Haufler CH, Ranker TA (1995) rbcL sequences provide phylogenetic insights among sister species of the fern genus Polypodium. American Fern Journal 85(4): 361-374. http://dx.doi. org/10.2307/1547815

Haufler CH, Soltis DE, Soltis PS (1995) Phylogeny of the Polypodium vulgare complex: insights from chloroplast DNA restriction site data. Systematic Botany 20(1): 110-119. http://dx.doi.org/10.2307/2419443

Hennipman E, Veldhoen P, Kramer KU, Price MG (1990) Polypodiaceae. In: Kramer KU, Green PS (Eds) The Families and Genera of Vascular Plants (Vol. 1) - Pteridophytes and Gymnosperms. Springer-Verlag, New York, 203-230. https://doi.org/10.1007/978-3662-02604-5_41

Hensen RV (1990) Revision of the Polypodium loriceum-complex (Filicales, Polypodiaceae). Nova Hedwigia 50(3-4): 279-336.

Hernández MA, Terán L, Mata M, Martínez OG, Prado J (2014) Helical cell wall thickenings in root cortical cells of Polypodiaceae species from Northwestern Argentina. American Fern Journal 103(4): 225-240. http://dx.doi.org/10.1640/0002-8444-103.4.225 
Hooker WJ (1844) Icones plantarum. Longman Rees, Orme, Brown, Green, \& Longman, London, $362 \mathrm{pp}$.

IUCN Standards and Petitions Subcommittee (2016) Guidelines for Using the IUCN Red List Categories and Criteria, version 12. Prepared by the Standards and Petitions Subcommittee. http://jr.iucnredlist.org/documents/RedListGuidelines.pdf [accessed 19.09.2016]

Janssen T, Schneider H (2005) Exploring the evolution of humus collecting leaves in drynarioid ferns (Polypodiaceae: Polypodiidae) based on phylogenetic evidence. Plant Systematics and Evolution 252(3): 175-197. http://dx.doi.org/10.1007/s00606-004-0264-6

Janssen T, Kreier H-P, Schneider H (2007) Origin and diversification of African ferns with special emphasis on Polypodiaceae. Brittonia 59(2): 159-181. http://dx.doi.org/10.1663/0007196X(2007)59[159:OADOAF]2.0.CO;2

Kreier H-P, Schneider H (2006) Phylogeny and biogeography of the staghorn fern genus Platycerium (Polypodiaceae: Polypodiidae). American Journal of Botany 93(2): 217-225. http:// dx.doi.org/10.3732/ajb.93.2.217

Kreier H-P, Rojas-Alvarado AF, Smith AR, Schneider H (2007) Hyalotrichopteris is indeed a Campyloneurum (Polypodiaceae). American Fern Journal 97(3): 127-135. http://dx.doi. org/10.1640/0002-8444(2007)97[127:HIIACP]2.0.CO;2

Kreier H-P, Rex M, Weising K, Kessler M, Smith AR, Schneider H (2008) Inferring the diversification of the epiphytic fern genus Serpocaulon (Polypodiaceae) in South America using chloroplast sequences and amplified fragment length polymorphisms. Plant Systematics and Evolution 274(1-2): 1-16. http://dx.doi.org/10.1007/s00606-008-0021-3

Kumar S, Stecher G, Tamura K (2016) MEGA7: Molecular Evolutionary Genetics Analysis version 7.0 for bigger datasets. Molecular Biology and Evolution 33(7): 1870-1874. http://doi.dx.org/10.1093/molbev/msw054

Labiak PH, Prado J (2008) New combinations in Serpocaulon and a provisional key for the Atlantic Forest species. American Fern Journal 98(3): 139-159. http://dx.doi. org/10.1640/0002-8444(2008)98[139:NCISAA]2.0.CO;2

Lellinger DB (2002) A modern multilingual glossary for taxonomic pteridology. Pteridologia 3: 1-263. https://doi.org/10.5962/bhl.title.124209

Minh BQ, Nguyen MAT, von Haeseler A (2013) Ultrafast approximation for phylogenetic bootstrap. Molecular Biology and Evolution 30(5): 1188-1195. http://dx.doi. org $/ 10.1093 / \mathrm{molbev} / \mathrm{mst} 024$

Moran RC (1995) Polypodiaceae. In: Davidse G, Sousa M, Knapp S (Eds) Flora Mesoamericana. (Moran RC, Riba R vol eds Psilotaceae a Salviniaceae) Universidad Nacional Autónoma de México, Ciudad del México, 333-366.

Nadot S, Bittar G, Carter L, Lacroix R, Lejeune B (1995) A phylogenetic analysis of monocotyledons based on the chloroplast gene rps4, using parsimony and a new numerical phenetics method. Molecular Phylogenetics and Evolution 4(3): 257-282. http://dx.doi. org/10.1006/mpev.1995.1024

Nguyen LT, Schmidt HA, von Haeseler A, Minh BQ (2015) IQ-TREE: A fast and effective stochastic algorithm for estimating maximum likelihood phylogenies. Molecular Biology and Evolution 32(1): 268-274. http://dx.doi.org/10.1093/molbev/msu300 
Otto EM, Janssen T, Kreier HP, Schneider H (2009) New insights into the phylogeny of Pleopeltis and related neotropical genera (Polypodiaceae, Polypodiopsida). Molecular Phylogenetics and Evolution 53(1): 190-201. http://dx.doi.org/10.1016/j. ympev.2009.05.001

Parris BS (1990) Grammitidaceae. In: Kubitzki K (Ed.) The Families and Genera of Vascular Plants I (Kramer KU, Green PS vol. eds. Pteridophytes and Gymnosperms). SpringerVerlag, New York, 153-156. https://doi.org/10.1007/978-3-662-02604-5_25

PPG I (2016) A community-derived classification for extant lycophytes and ferns. Journal of Systematics and Evolution 54(6): 563-603. https://doi.org/10.1111/jse.12229

Rambaut A, Suchard MA, Xie D, Drummond AJ (2014) Tracer v1.6. Available from: http:// beast.bio.ed.ac.uk/Tracer [accessed 01.10.2016]

Ronquist F, Teslenko M, van der Mark P, Ayres DL, Darling A, Höhna S, Larget B, Liu L, Suchard MA, Huelsenbeck J (2012) MrBayes 3.2: Efficient Bayesian phylogenetic inference and model choice across a large model space. Systematic Biology 61(1): 1-4. http://dx.doi. org/10.1093/sysbio/sys029

Salino A, Almeida TE, Smith AR, Gómez AN, Kreier H-P, Schneider H (2008) A new species of Microgramma (Polypodiaceae) from Brazil and recircumscription of the genus based on phylogenetic evidence. Systematic Botany 33(4): 630-635. http://dx.doi. org/10.1600/036364408786500208

Sanín D (2014) Serpocaulon obscurinervium (Polypodiaceae), a new fern species from Colombia and Ecuador. Plant Ecology and Evolution 147(1): 127-133. http://dx.doi.org/10.5091/ plecevo.2014.915

Sanín D (2015) Serpocaulon tayronae (Polypodiaceae), a new species from the Sierra Nevada de Santa Marta, Colombia. Phytotaxa 213(3): 243-252. http://dx.doi.org/10.11646/phytotaxa.213.3.4

Schneider H, Smith AR, Cranfill R, Haufler CH, Ranker TA, Hildebrand T (2002) Gymnogrammitis dareiformis is a polygrammoid fern (Polypodiaceae) - Resolving an apparent conflict between morphological and molecular data. Plant Systematics and Evolution 234(1-4): 121-136. http://dx.doi.org/10.1007/s00606-002-0207-z

Schneider H, Smith AR, Cranfill R, Hildebrand TJ, Haufler CH, Ranker TA (2004) Unraveling the phylogeny of polygrammoid ferns (Polypodiaceae and Grammitidaceae): exploring aspects of the diversification of epiphytic plants. Molecular Phylogenetics and Evolution 31(3): 1041-1063. http://dx.doi.org/10.1016/j.ympev.2003.09.018

Schneider H, Kreier H-P, Wilson R, Smith AR (2006) The Synammia enigma: evidence for a temperate lineage of Polygrammoid ferns (Polypodiaceae, Polypodiidae) in Southern South America. Systematic Botany 31(1): 31-41. http://dx.doi.org/10.1600/036364406775971868

Schuettpelz E, Pryer KM (2007) Fern phylogeny inferred from 400 leptosporangiate species and three plastid genes. Taxon 56(4): 1037-1050. http://dx.doi.org/10.2307/25065903

Schwarz G (1978) Estimating the dimension of a model. Annals of Statistics 6(2): 461-464. https://doi.org/10.1214/aos/1176344136

Sigel EM, Windham MD, Haufler CH, Pryer KM (2014) Phylogeny, divergence time estimates, and phylogeography of the diploid species of the Polypodium vulgare complex (Polypodiaceae). Systematic Botany 39(4): 1042-1055. http://dx.doi.org/10.1600/036364414X683921 
Smith AR, Cranfill RB (2002) Intrafamilial relationships of the thelypteroid ferns. American Fern Journal 92(2): 131-149. http://dx.doi.org/10.1640/0002-8444(2002)092[0131:IR OTTF]2.0.CO;2

Smith AR, Kreier HP, Haufler CH, Ranker TA, Schneider H (2006a) Serpocaulon (Polypodiaceae), a new genus segregated from Polypodium. Taxon 55(4): 919-930. https://doi. org/10.2307/25065686

Smith AR, Pryer KM, Schuettpelz E, Korall P, Schneider H, Wolf PG (2006b) A classification for extant ferns. Taxon 55(3): 705-731. https://doi.org/10.2307/25065646

Smith AR, Pryer KM, Schuettpelz E, Korall P, Schneider H, Wolf PG (2008) Fern classification. In: Ranker TA, Haufler CH (Eds) Biology and Evolution of Ferns and Lycophytes. Cambridge University Press, Cambridge, 417-467. https://doi.org/10.1017/ CBO9780511541827.017

Smith AR, Tejero-Díez JD (2014) Pleopeltis (Polypodiaceae), a redefinition of the genus and nomenclatural notes. Botanical Sciences 92(1): 43-58. https://doi.org/10.17129/botsci.29

Sundue MA, Islam MB, Ranker TA (2010) Systematics of grammitid ferns (Polypodiaceae): using morphology and plastid sequence data to resolve the circumscription of Melpomene and the polyphyletic genera Lellingeria and Terpsichore. Systematic Botany 35(4): 701-715. https://doi.org/10.1600/036364410X539790

Tejero-Díez JD (2005) Revisión taxonómica del complejo Polypodium plesiosorum Kunze (Polypodiaceae, Polypodiophyta). PhD Thesis, Universidad Autónoma Metropolitana, Mexico DF, 187 pp.

Tryon AF, Lugardon B (1991) Spores of the Pteridophyta. Springer-Verlag, New York, 648 pp. https://doi.org/10.1007/978-1-4613-8991-0_1

Tryon RM, Tryon AF (1982) Ferns and Allied plants, with Special Reference to Tropical America. Springer-Verlag, New York, 835 pp. https://doi.org/10.1007/978-1-4613-8162-4_1

Tryon RM, Stolze RG, León B (1993) Pteridophyta of Peru V - Aspleniaceae-Polypodiaceae. Fieldiana, Botany (NS) 32: 1-189. http://dx.doi.org/10.5962/bhl.title.2547 


\section{Appendix}

Collection information for voucher specimens and GenBank accession numbers for sequences used in this study. Locality and voucher specimen (herbarium) are given to sequences newly generated in this study. *sequences submitted to GenBank

\begin{tabular}{|c|c|c|}
\hline Taxon & $r b c \mathrm{~L}$ & $r p s 4-t r n S$ \\
\hline Adenophorus oahuensis (Copel.) L.E.Bishop & AY057382 & AY096236 \\
\hline Adetogramma chrysolepis (Hook.) T.E.Almeida; Bolivia, Almeida 3083 (BHCB) & KY847865* & KY847858* \\
\hline Adetogramma chrysolepis (Hook.) T.E.Almeida; Bolivia, Almeida 3121 (BHCB) & KY847859* & KY847863* \\
\hline Aglaomorpha pilosa (J.Sm.) Copel. & AY529156 & AY529180 \\
\hline Alansmia cultrata (Willd.) Moguel \& M.Kessler & GU376496 & JN654943 \\
\hline Arthromeris himalayensis (Hook.) Ching & JQ685378 & JQ685442 \\
\hline Campyloneurum gracile A.Rojas; Panama, Salino 15357 (BHCB) & KY847860* & KY847864* \\
\hline Campyloneurum phyllitidis (L.) C.Presl & KT780752 & KT794132 \\
\hline Davallia solida (G.Forst.) Sw. & AY096193 & AY096210 \\
\hline Dictymia brownii (Wikstr.) Copel. & DQ227292 & DQ227295 \\
\hline Goniophlebium percussum (Cav.) W.H.Wagner \& Grether & AY362561 & AY362628 \\
\hline Gymnogrammitis dareiformis (Hook.) Tardieu \& C.Chr. & AY096201 & JQ685456 \\
\hline Lecanopteris carnosa (Reinw.) Blume & AF470322 & AY096227 \\
\hline Lellingeria apiculata (Klotzsch) A.R.Sm. \& R.C.Moran & GU387021 & GU387046 \\
\hline Lellingeria brevistipes (Kuhn) A.R.Sm. \& R.C.Moran & GU387030 & GU387049 \\
\hline Lemmaphyllum carnosum (Hook.) C.Presl & GU126698 & GU126717 \\
\hline Lepidomicrosorium subhemionitideum (Christ) P.S.Wang & GU126693 & GU126711 \\
\hline Lepisorus heterolepis (Rosenst.) Ching & GQ256270 & GQ256344 \\
\hline Leptochilus digitatus (Baker) Noot. & JX103695 & EU363250 \\
\hline Leucotrichum madagascariense Rakotondr. \& Rouhan & JN654924 & JN654949 \\
\hline Leucotrichum organense (Gardner) Labiak & GU376490 & JN654946 \\
\hline Loxogramme salicifolia (Makino) Makino & DQ227294 & DQ227297 \\
\hline Melpomene flabelliformis (Poir.) A.R.Sm. \& R.C.Moran & GU387028 & GU387114 \\
\hline Melpomene melanosticta (Kunze) A.R.Sm. \& R.C.Moran & GU387024 & GU387115 \\
\hline Microgramma baldwinii Brade; Brazil, Almeida 2631 (BHCB) & KY847861* & KY847866* \\
\hline Microgramma bifrons (Hook.) Lellinger & AY362582 & AY362654 \\
\hline Microgramma mauritiana (Willd.) Tardieu & DQ642148 & DQ642185 \\
\hline Microgramma persicariifolia (Schrad.) C.Presl & KT780753 & KT794133 \\
\hline Microsorum membranaceum (D.Don) Ching & EU482963 & AY725047 \\
\hline Mycopteris attenuatissima (Copel.) Sundue & GU476927 & GU387121 \\
\hline Mycopteris subtilis (Klotzsch) Sundue & GU476875 & GU387128 \\
\hline Neocheiropteris palmatopedata (Baker) Christ & JX103706 & GQ256396 \\
\hline Niphidium crassifolium (L.) Lellingerl; Brazil, Almeida 3247 (BHCB) & KY847862* & KY847867* \\
\hline Niphidium nidulare (Rosenst.) Lellinger & EF551064 & EF551080 \\
\hline Oleandra pistillaris (Sw.) C.Chr & AB232405 & AY096209 \\
\hline Pecluma ptilotos (Kunze) M.G.Price & AY362588 & AY362661 \\
\hline Phlebodium pseudoaureum (Cav.) Lellinger & AY362589 & AY362663 \\
\hline Platycerium andinum Baker & DQ164446 & DQ164477 \\
\hline Pleopeltis angusta Willd. & EU650122 & EU650161 \\
\hline Pleopeltis desvauxii (Klotzsch) Salino & AY362584 & AY362657 \\
\hline Polypodium vulgare $\mathrm{L}$. & JF832081 & EF551081 \\
\hline
\end{tabular}




\begin{tabular}{l|c|c}
\hline \multicolumn{1}{c|}{ Taxon } & rbcL & rps4-trnS \\
\hline Pyrrosia angustata (Sw.) Ching & DQ642165 & DQ642204 \\
\hline Selliguea plantaginea Brack. & EF463262 & EU128510 \\
\hline Serpocaulon articulatum (C.Presl) Schwartsb. \& A.R.Sm. & DQ151910 & DQ151935 \\
\hline Serpocaulon dissimile (L.) A.R.Sm. & DQ151908 & DQ151933 \\
\hline Serpocaulon levigatum (Cav.) A.R.Sm. & DQ151917 & EF551103 \\
\hline Serpocaulon loriceum (L.) A.R.Sm. & EF551074 & EF551104 \\
\hline Stenogrammitis hellwigii (Mickel \& Beitel) Labiak & GU386990 & GU387058 \\
\hline Stenogrammitis hildebrandtii (Hieron.) Labiak & GU386975 & GU387059 \\
\hline Synammia feuillei (Bertero) Copel. & AY362597 & AY362670 \\
\hline
\end{tabular}

